\section{Use of Irrigation Technologies for Vegetable Crops in Florida}

\author{
Michael D. Dukes ${ }^{1}$, Lincoln Zotarelli ${ }^{1,3}$, and Kelly T. Morgan ${ }^{2}$
}

ADDITIONAL INDEX wORDs. soil water, moisture sensors, drip, control systems, scheduling, uniformity

SUMMARY. Major horticultural crops in Florida are vegetables, small fruit, melons, and tree fruit crops. Approximately half of the agricultural area and nearly all of the horticultural crop land is irrigated. Irrigation systems include low-volume microirrigation, sprinkler systems, and subsurface irrigation. The present review was divided into two papers, in which the first part focuses on vegetable crop irrigation and the second part focuses on fruit tree crop irrigation. This first part also provides an overview of irrigation methods used in Florida. Factors affecting irrigation efficiency and uniformity such as design and maintenance are discussed. A wide range of soil moisture sensors (e.g., tensiometers, granular matrix, and capacitance) are currently being used in the state for soil moisture monitoring. Current examples of scheduling tools and automated control systems being used on selected crops in Florida are provided. Research data on the effect of irrigation scheduling and fertigation on nutrient movement, particularly nitrate, are reviewed. Concluding this review is a discussion of potential for adoption of irrigation scheduling and control systems for vegetable crops by Florida growers and future research priorities.

$\mathrm{F}$ lorida is a top water user in the humid region of the United States, ranking second in withdrawal of groundwater for public supply in the United States and ranking 13th nationally for agricultural water use (Solley et al., 1998). Agriculture accounts for 35\% of Florida fresh groundwater withdrawals and $60 \%$ of fresh surface water withdrawals. This category is the largest component of freshwater use with $45 \%$ of the total withdrawals in Florida (Marella, 1999).

An approach to conserving water is to maximize the irrigation efficiency and to minimize water loss. Irrigation efficiency is a measure of 1 ) the effectiveness of an irrigation system in delivering water to a crop; 2) the effectiveness of irrigation in increasing crop yields; and 3 ) effectiveness of reducing nutrient leaching. Irrigation practices imply high irrigation efficiency and can be achieved by maintaining irrigation water application uniformity and improving water uptake efficiency of the irrigation water. Uniformity is a measure of how well

${ }^{1}$ Department of Agricultural and Biological Engineering, University of Florida, 263 Frazier Rogers Hall, Museum Road, P.O. Box 110570, Gainesville, FL, 32611-0570

${ }^{2}$ Soil and Water Science Department, University of Florida, Southwest Florida REC, 2686 SR 29 N, Immokalee, FL 34142

${ }^{3}$ Corresponding author. E-mail: lzota@ufl.edu. water is distributed to the plants in a given field and is often expressed as a measure of variability. Crop uptake efficiency may be expressed as the ratio of crop yield or increase in yield over nonirrigated production to the volume of irrigation water used. Irrigation efficiencies thus provide a basis for the comparison of irrigation systems from the standpoint of water beneficially used and from the standpoint of yield per unit of water used (Howell, 2001). Irrigation system efficiency depends primarily on three components: 1) design; 2) installation and maintenance; and 3) management. The recommendations of the University of Florida, Institute of Food and Agriculture Sciences for irrigation management and best management practices (BMPs) of horticultural crops include the following: using a combination of target irrigation volume; a measure of soil moisture to adjust this volume based on crop age and weather conditions; knowledge of how much the root zone can hold; and an assessment of how rainfall contributes to replenishing soil moisture (Hochmuth, 2007).

\section{Irrigation in Florida}

Nationally, 53.1 million acres of crop land are irrigated. There are $3,715,253$ acres of crop land in Florida according to U.S. Department of Agriculture (USDA, 2004a). In $2003, \approx 1,815,172$ acres of land were irrigated and $62 \%$ of harvested crop land was irrigated in the same year (USDA, 2004b). In terms of irrigation, virtually all horticultural production is irrigated in Florida as a result of the economic value of these crops and relatively low water-holding capacity of the sandy soils. These crops include 748,360 acres of tree fruit crops [mostly citrus (Citrus spp.)], 120,306 acres of vegetables [including 37,782 acres of tomato (Solanum lycopersicum) ], 49,831 acres of potato (Solanum tuberosum), 14,629 acres of sweet corn (Zea mays var. saccharata), and 5,683 acres of strawberry (Fragaria $\times$ ananassa) (USDA, 2004b).

Although Florida ranks 11 th in irrigated area nationally (Fig. 1), it is surpassed by only Arkansas in the eastern United States (USDA, 2004b). Irrigated area in Florida has increased from $\approx 395,000$ acres in 1954 to the current level (Smajstrla and Haman, 1998; USDA, 2004b) as shown in Figure 2.

Irrigated area in Florida spans a wide range of irrigation delivery systems depending on the type of crop and cultural conditions. Irrigation can be grouped into the following general categories: low volume (also known as microirrigation, trickle irrigation, or drip irrigation), sprinkler, surface (also known as gravity or flood irrigation), and subirrigation or seepage irrigation (a variation on subsurface irrigation or water table control in other parts of the United States). Microirrigation and sprinkler irrigation account for $6 \%$ and $50 \%$, respectively, on a national basis (USDA,

\begin{tabular}{llll}
\hline $\begin{array}{l}\text { Units } \\
\text { To convert U.S. to SI, } \\
\text { multiply by }\end{array}$ & U.S. unit & SI unit & $\begin{array}{l}\text { To convert SI to U.S., } \\
\text { multiply by }\end{array}$ \\
\hline 0.4047 & acre(s) & $\mathrm{ha}$ & 2.4711 \\
100 & $\mathrm{bar}$ & $\mathrm{kPa}$ & 0.01 \\
0.3048 & $\mathrm{ft}$ & $\mathrm{m}$ & 3.2808 \\
2.54 & inch(es) & $\mathrm{cm}$ & 0.3937 \\
25.4 & inch(es) & $\mathrm{mm}$ & 0.0394
\end{tabular}


2004a). The largest fraction of irrigated land in Florida is microirrigation (45\%, Fig. 3A), which is largely the result of microsprinkler irrigation of citrus, which accounts for the largest crop area in the state. Sprinkler irrigation accounts for $11 \%$ of the irrigated land. Florida-irrigated agriculture is thus more water use efficient compared with U.S. agriculture in general as a result of greater application efficiency of microirrigation compared with sprinkler irrigation.

The USDA for many years has ranked gravity irrigation as very high in Florida (USDA, 2004a); however, we believe this nomenclature is incorrect. Strictly speaking, gravity irrigation does not use an artificial power source (i.e., pump) to move water and relies on water infiltrating the ground from the surface. There are a few flood irrigation systems in Florida; the authors believe that gravity and seepage (i.e., subirrigation by the USDA) categories refer to the same type of irrigation system where irrigation is primarily the result of upward movement of water from capillarity resulting from an artificially maintained water table (Fig. 3B). This water table is typically maintained by water furrows where an outlet from a pressurized source is used to deliver water to the furrow (spaced every 60 $\mathrm{ft}$ ) and thereby maintains the shallow water table. In contrast, gravity irrigation uses water diverted from surface canals to flood entire fields or to flood furrows and then relies on capillarity to move water laterally to the crop root zone. Descriptions of these irrigation methods and their relative efficiencies follow.

\section{Irrigation of vegetables and melons}

The estimated area planted with vegetables and melons in the United States in 2007 was greater than 1.9 million acres and the estimated value of the crop was $\$ 10.9$ billion nationwide (USDA, 2008b). The four largest vegetable crops, in terms of U.S. production, are onion (Allium cepa), head lettuce (Lactuca sativa), tomato, and watermelon (Citrullus lanatus), which combined account for $65 \%$ of the total production. In particular, vegetable crop cultivation areas are concentrated in the west, southeast, northwest, and Great Lakes regions of

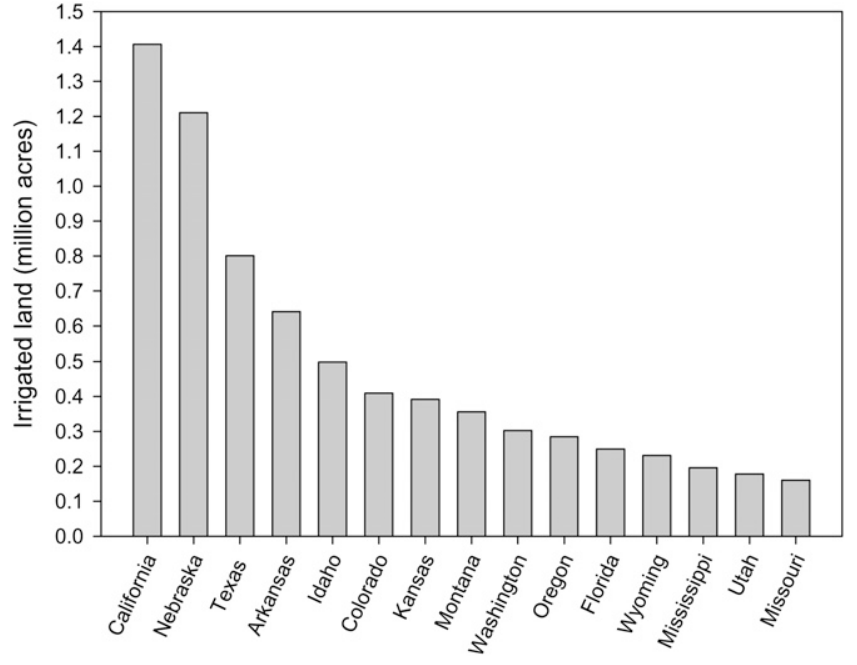

Fig. 1. Irrigated area for states with more than 989,000 acres irrigated according to from the U.S. Department of Agriculture (2004b); 1 acre $=0.4047$ ha.

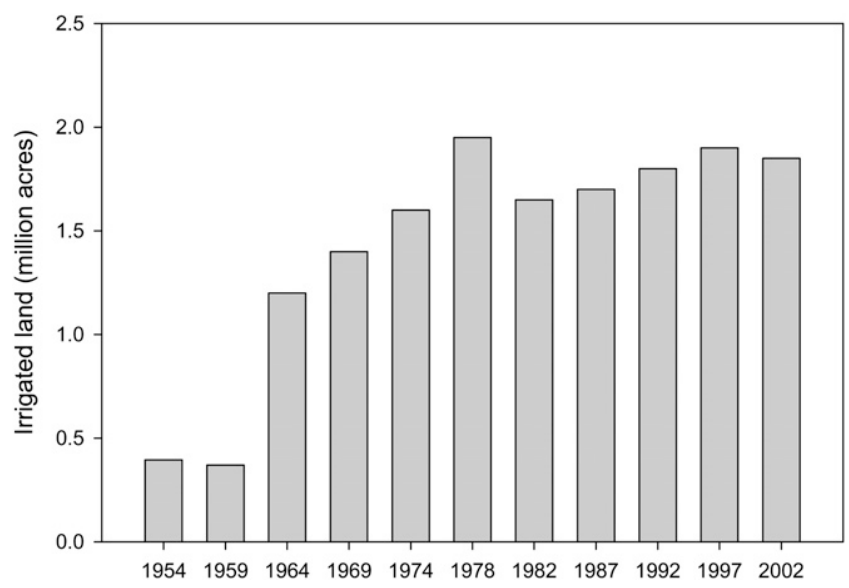

Fig. 2. Irrigated land in Florida over time according to the U.S. Department of Agriculture (2004b); 1 acre $=0.4047$ ha.
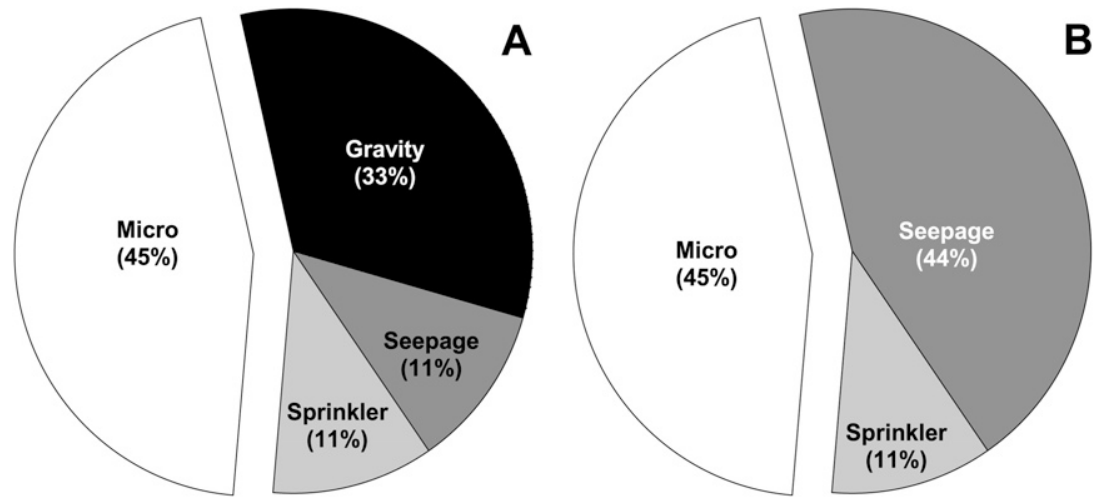

Fig. 3. (A) Percentage of total irrigated land by irrigation delivery method according to the U.S. Department of Agriculture (USDA, 2004b) and (B) authors' interpretation of USDA data as related to Florida irrigation systems. Note that USDA numbers were adjusted slightly to maintain a $100 \%$ total.

the United States and the leading states in the order of area and dollar value are California, Florida, Georgia, Arizona, and New York.
Florida is the most important center of production and distribution of vegetables in the southeastern United States with 181,000 acres 
planted in 2006 and a crop value greater than $\$ 1.2$ billion (USDA, 2008b) (Figs. 4 and 5). Among the vegetable crops cultivated in Florida, tomato, bell pepper (Capsicum annuиm), sweet corn, strawberry, snap bean (Phaseolus vulgaris), and cucumber (Cucumis satious) are very important economically (Fig. 4).

Tomato is the most important vegetable commodity in Florida in terms of planted area and crop value. Between 1998 and 2006, the planted area with tomato averaged 42,601 acres, $\approx 20 \%$ of the total vegetable area planted in the state (Fig. 4). However, high crop value is attached to tomato production, because the average tomato crop value during

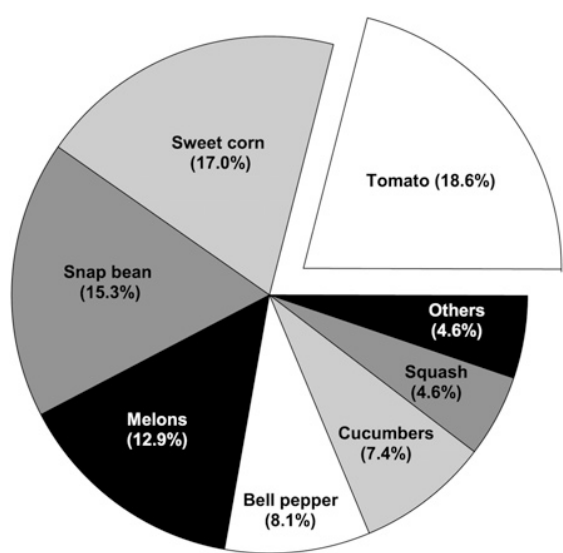

Fig. 4. Percentage of planted area with vegetables in Florida, average values between 1998 and 2006 according to the U.S. Department of Agriculture (2008a).

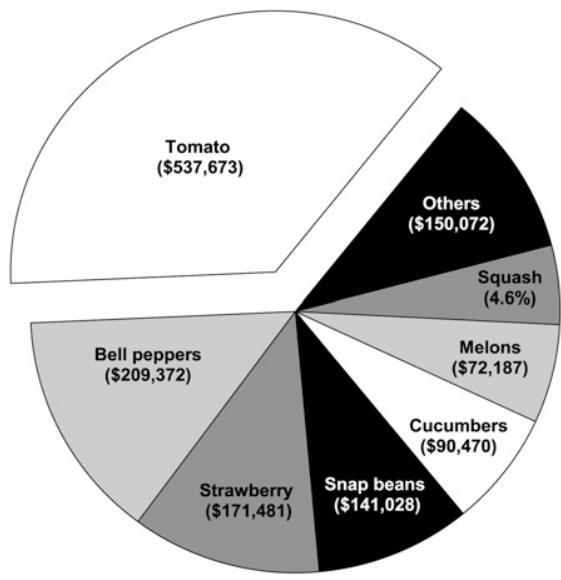

Fig. 5. Crop value $(\times \$ 1000)$ of vegetables produced in Florida; average values between 1998 and 2006 according to the U.S. Department of Agriculture (2008a). the same period was $\$ 537$ million (Fig. 5 ) representing $38 \%$ of the total crop value of all state vegetables according to Florida Department of Agriculture and Consumer Services (FDACS, 2007). Southern Florida has the largest number of tomato farms in the state and in this area, there is a predominance of seepage irrigation. Other important production areas are Hillsborough, Dade, and Gadsden counties with predominance of drip irrigation.

Sweet corn in Florida has $\approx 38,785$ acres planted annually, and the crop value is $\approx \$ 108$ million (Fig. 5). Sweet corn is predominantly grown in Palm Beach and Miami-Dade counties and the irrigation management is mainly sprinkler sometimes combined with seepage irrigation. Snap bean has $\approx 32,865$ acres planted annually in Florida. This crop is grown in several counties in Florida; the most important are Miami-Dade, Hendry, Palm Beach, and Alachua. Snap beans are typically irrigated by sprinklers in Dade and Alachua counties and seepage in Hendry and Palm Beach counties. Watermelon is broadly cultivated in Florida with $\approx 23,000$ acres planted in the state annually. The irrigation methods for this crop are drip irrigation and seepage irrigation, depending on the region within the state. The counties with drip irrigation are Suwannee, Manatee, Levy, Alachua, and Marion. Watermelon is grown using seepage irrigation in Hendry, Charlotte, Collier, and Desoto counties. Bell pepper is the second most important vegetable produced in Florida in terms of value. With a crop value of $\$ 209$ million, the average area annually planted with bell peppers in Florida is 18,533 acres. Palm Beach County has the largest area cultivated with bell pepper followed by Collier and Hillsborough counties, predominantly seepage irrigation. Strawberry is the most valuable crop per unit area in Florida. The average annual crop value is $\approx \$ 171$ million (Fig. 5); however, the area planted with this crop represents only $3 \%(6,700$ acres $)$ of the total area planted of fruit and vegetables in Florida. Strawberry production is concentrated in Alachua, Pasco, Hillsborough, and Polk counties and uses drip irrigation as well as sprinkler irrigation for frost protection. Approximately $80 \%$ of Florida strawberry area is drip-irrigated (Haman et al., 2005).

The irrigation of vegetable crops in Florida is classified in sprinkler, microirrigation systems, and seepage irrigation. Sprinkler systems are designed to use overlapping patterns to provide uniform coverage over an irrigated area. These types of systems have been frequently used under row vegetable crops such as sweet corn, potato, and snap beans, which are vegetable crops not cultivated with plastic mulch. Sprinklers are normally spaced $50 \%$ to $60 \%$ of their diameter of coverage to provide uniform application in low wind conditions. Studies have shown that $1.5 \%$ to $7.6 \%$ of irrigated water can be lost as a result of wind drift and evaporation during application (Frost and Schwalen, 1960; Kohl et al., 1987). Application efficiencies of sprinkler systems are typically less than $80 \%$. Because networks of pressurized pipelines are used to distribute water in these systems, the uniformity of water application and the irrigation efficiency are more strongly dependent on the hydraulic properties of the pipe network. Thus, application efficiencies of well-designed and well-managed pressurized sprinkler systems are much less variable than application efficiencies of seepage or surface irrigation systems, which depend heavily on soil hydraulic characteristics. Therefore, during water applications, sprinkler irrigation systems lose water as a result of evaporation and wind drift (Haman et al., 2005). More water is lost during windy conditions than calm conditions. More is also lost during high evaporative demand periods (hot, dry days) than during low-demand periods (cool, cloudy, humid days). Thus, sprinkler irrigation systems usually apply water more efficiently at night (and early mornings and late evenings) than during the day. It is not possible to apply water with perfect uniformity because of friction losses, elevation changes, manufacturing variation in components, and other factors. Traveling guns typically have greater application efficiencies than portable guns because of the greater uniformity that occurs in the direction of travel (Smajstrla et al., 2002). Periodic move lateral systems are designed to apply water uniformly along the laterals. Nonuniformity and low 
application efficiencies occur when the laterals are not properly positioned between settings. Nonuniformity also occurs at the ends of the laterals where sprinkler overlap is not adequate (Smajstrla et al., 2002).

Application efficiencies of microirrigation systems are typically high because these systems distribute water near or directly into the crop root zone; water losses resulting from wind drift and evaporation are typically small (Boman, 2002; Locascio, 2005). This highly efficient water system $(90 \%$ to $95 \%)$ is widely used on high-value vegetables and tree fruit crops. The advantages of microirrigation over sprinkler include: reduced water use, ability to apply fertilizer with the irrigation, precise water distribution, reduced foliar diseases, and the ability to electronically schedule irrigation on large areas with smaller pumps relative to sprinkler systems. If microsprinkler systems are operated under windy conditions on hot, dry days, wind drift and evaporation losses can be high. Thus, management to avoid these losses is important to achieving high application efficiencies with these systems. Therefore, management to avoid these losses is important to achieve high application efficiency. The most common application of microirrigation in Florida is that of under-tree microsprinkler systems for citrus. Less efficiency has been found for microsprinkler system compared with drip irrigation. Application efficiencies of drip and line source systems are primarily dependent on hydraulics of design of these systems and on their maintenance and management (Boman, 2002). It is thought that drip irrigation gives the higher application efficiency for vegetables in Florida $(80 \%$ to $90 \%)$ compared with seepage $(20 \%$ to $50 \%)$ and overhead irrigation systems (60\% to $80 \%$ ) (Simmone et al., 2007).

In seepage or flood systems, water is distributed by flow through the soil profile or over the soil surface. The uniformity and efficiency of the irrigation water applied by this method depends strongly on the soil topography and hydraulic properties (Boman, 2002). Florida's humid climate requires drainage on high water table soils, and field slope is necessary for surface drainage. However, surface runoff also occurs because of field slope. Runoff reduces irrigation apis collected in retention ponds and used for irrigation at a later time (Smajstrla et al., 2002). Water distribution from seepage irrigation systems occurs below the soil surface. Therefore, wind and other climatic factors do not affect the uniformity of water application. Use of a welldesigned and well-maintained irrigation system reduces the loss of water and thereby increases application efficiency as well as uniformity (Boman, 2002).

Approximately $44 \%$ of Florida irrigated area uses seepage irrigation; most of this area is under high-value crop production such as fresh market vegetables and potato. Unfortunately, this type of irrigation has very low efficiency as a result of the large amount of water required to constantly maintain a shallow water table throughout the crop season, which may cause nutrient leaching (Pandey et al., 2007). However, growers like this type of irrigation system as a result of its relative ease of operation (e.g., constant pumping during the season) and because the infrastructure costs are much lower than with systems such as drip irrigation. Thus, as water supplies become strained, one option to increase irrigation efficiency is conversion from seepage to drip irrigation.

\section{Application uniformity}

One important irrigation management factor is irrigation uniformity, plication efficiencies unless this water

which is how evenly water is distributed across the field. Nonuniform distribution of irrigation water (Figs. 6 and 7) may create zones of overand/or under-irrigation, which can lead to yield reduction resulting from excessive nutrient leaching or plant water stress.

For a sprinkler irrigation system, the uniformity of application can be evaluated by placing containers in a geometric configuration and measuring the amount of water caught in each container. Dukes (2006) used this type of testing to show that effect of pressure and wind speed on operating performance of two types of center pivot sprinkler system nozzle packages. Furthermore, Dukes and Perry (2006) showed that uniformity of a variable rate control system was not different from a traditional control system on two typical center pivot/linear move irrigation systems used in the southeastern United States. However, the problem of sprinkler systems is that the water application pattern is susceptible to distortion by the wind. Although wind speed and direction are not controlled variables, their effect on irrigation uniformity is significant so that sprinkler system design must be done with anticipated wind conditions. Under windy conditions, the spacing between laterals when possible should be reduced to optimize the application uniformity. Maintenance of adequate water pressure through the entire systems, repairing leaks and

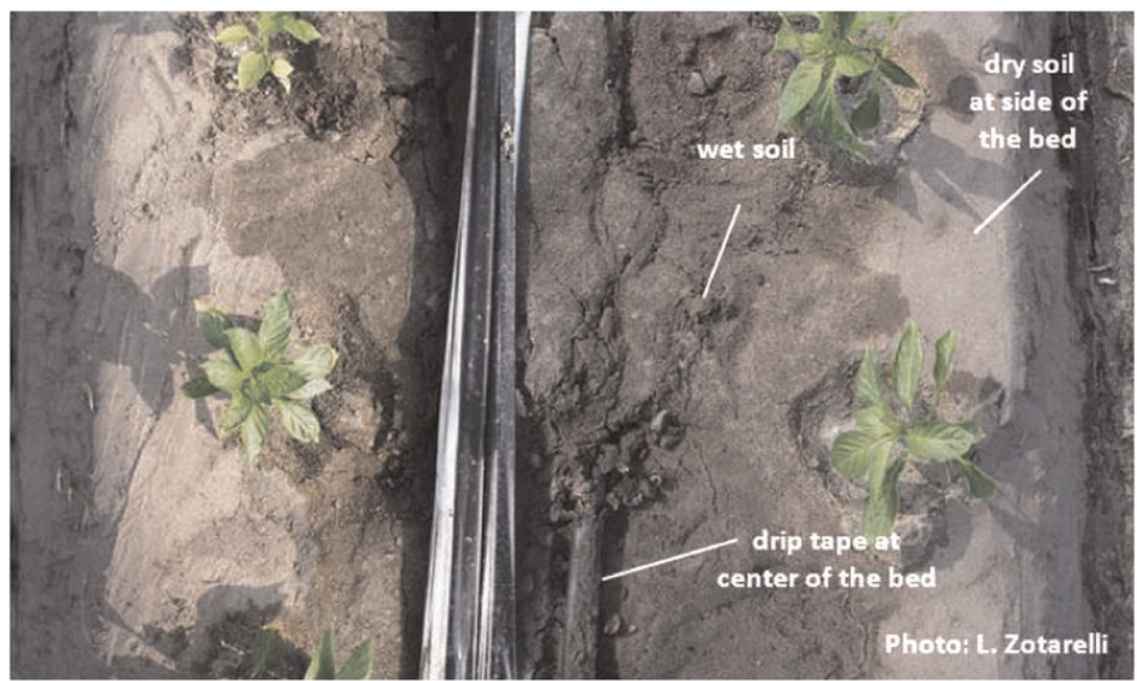

Fig. 6. Photograph of lateral movement of irrigated water for pepper crop in a sandy soil after $1 \mathrm{~h}$ of irrigation. 


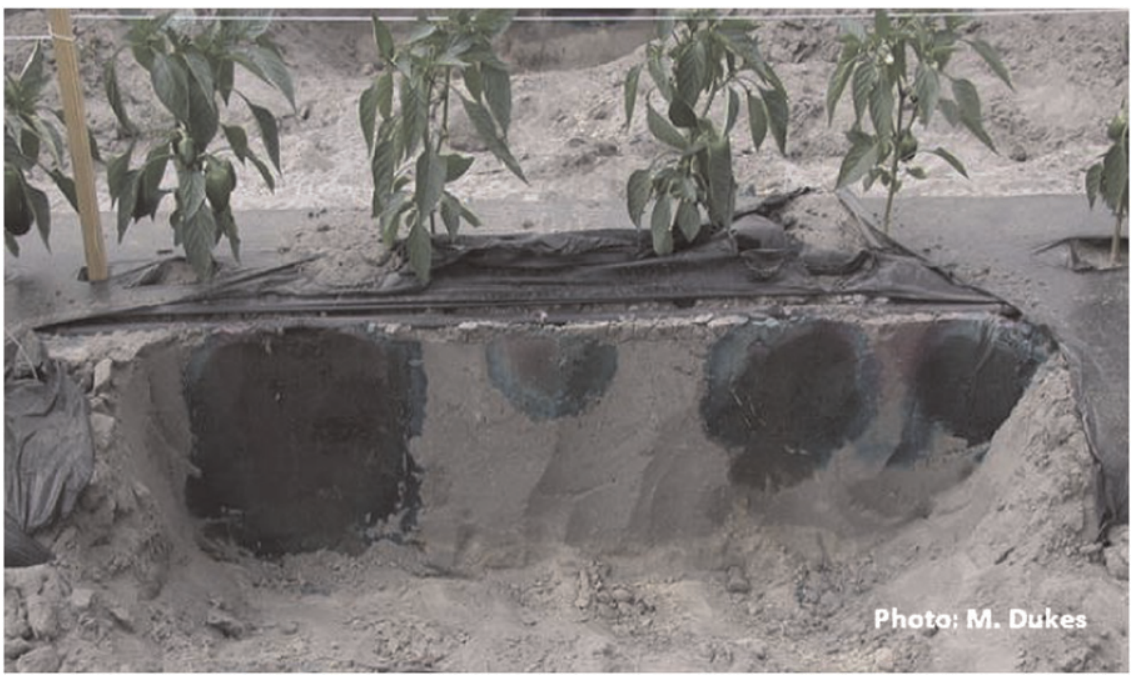

Fig. 7. Photograph of drip irrigation on a pepper field. Detail of nonuniformity of water application as a result of emitter clogging.

replacing malfunctioning sprinklers, is also a way to improve the irrigation uniformity.

Drip irrigation systems are very efficient in terms of water distribution and reduction of water losses. The uniformity is directly related to the pressure variation within the entire system and the variability of the emissions of each individual emitter. Several factors contribute to reduce the uniformity of water application such as excessive length of laterals, excessive pressure losses resulting from changes in elevation along the laterals, emitter clogging, and soil characteristics. Specifically for drip irrigation in which the number of point sources of water (emitters) is limited, the uniformity of application can be compromised by the soil characteristics, leading to very intense water percolation during long irrigation events. The water-holding capacity of sandy soils is very low because of the large spaces between soil particles (macropores with diameter larger than $0.06 \mathrm{~mm}$ ), through which water can pass rapidly.

Conversely, for finer texture soils, smaller pore sizes are dominant and the result of capillarity higher lateral movement is expressed. The important aspect of such flow in sandy soils (most of Florida soils) is that water and nutrients (particularly nitrate) can infiltrate downward through soil profile much faster than finer soils. It is also important to point out that preferential pathways lead to dramatic reduction in wetted soil volume and an increase in nutrient leaching, which can be crucial for root development, plant growth, and yield on many vegetables. The limited lateral water movement in sandy soils under drip irrigation drastically affects the root distribution (Zotarelli et al., 2009) and nutrient interception in the sides of the raised bed (Fig. 6). This could be a problem for doublerow crops like peppers and squash when a single drip tape in center of the bed is placed.

Nonuniform distribution of water in the bed may also compromise the acquisition of nutrients by the root system. Because nitrate is a highly mobile, nonadsorbing ion, low rooting densities may not be sufficient for nitrate acquisition, and a larger fraction of the nitrogen applied through fertigation can escape below the root zone. The basis for this lies in previous field observations, which demonstrated that the displacement of irrigation water and nutrients is primarily vertical and confined to a 30 to $40-\mathrm{cm}$ wide zone as a result of the extremely high hydraulic conductivity of our sandy soils. With the use of conventional irrigation practices such as single application, water and nutrients are thus displaced up to $100 \mathrm{~cm}$ within 1 week, whereas the effective vegetable root zone may only be 30 to $60 \mathrm{~cm}$ deep. The use of appropriate irrigation scheduling facilitates more frequent applications of small volumes of water and improves matching of water supply and crop water demand, which is critical to reduce potential crop water stress and leaching losses in sandy soils (Zotarelli et al., 2008a, 2008b, 2009). Because applying frequent small-volume irrigation with conventional systems tends to be labor-intensive and/or technically difficult to use, sensorbased irrigation systems may facilitate the successful use of low-volume, high-frequency irrigation systems in commercial vegetable systems. In addition, reduction in emitter spacing and also the use of double drip tapes placed closer to the crop rows may improve the uniformity of water and nutrient distribution along the beds while reducing the amount of water required. However, there is a lack of information about the effectiveness of this system for double-row crops.

\section{Irrigation system maintenance}

Microirrigation systems are technically more complex than overhead sprinkler or flood irrigation systems. Low-volume irrigation systems require significant maintenance to assure maximum operational efficiency. The performance of a microirrigation system may rapidly deteriorate if it is not routinely maintained properly (Obreza, 2004). Maintenance to improve system uniformity includes checking for leaks, backwashing and cleaning filters, periodic line flushing, chemical injection (e.g., chlorinating and acidifying), and cleaning or replacing plugged emitters. For example, in irrigation water that contains sand, a sand separator should be used. Clogging may occur when no filter or the incorrect type of filter is used resulting in poor water distribution uniformity and crop loss. Figure 7 shows the effect of clogged emitters in the water distribution in the root zone of bell pepper. Proper maintenance of a microirrigation system will extend system life, improve performance, minimize downtime, reduce the probability of nonuniform water and fertilizer applications resulting from emitter plugging, reduce operating costs, and save water and fertilizer.

\section{Irrigation scheduling}

Irrigation scheduling consists simply of applying water to crops at the "right" time and in the "right" amount and it is considered an important BMP. Scheduling often consists of grower judgment or a 
calendar-based schedule of irrigation events based on previous seasons. Several factors such as plant evaporative demand, soil characteristics, and root distribution are taken into account as well to establish proper irrigation scheduling (Locascio, 2005). The simplest form of scheduling is the "feel" method as outlined by the USDA (1998). A wide range of irrigation scheduling methods is used in Florida with corresponding levels of water management. The recommended method for scheduling irrigation (drip or overhead) for vegetable crops is to use together 1) the crop water requirement method that takes into account plant stage of growth;2) a measurement of soil water status; and 3 ) guidelines for splitting irrigation into small events so as not to exceed the soil water holding capacity (Simmone et al., 2007).

Soils hold different amounts of water depending on their pore size distribution and their structure. The upper limit of water-holding capacity is often called "field capacity" (FC), whereas the lower limit is called the "permanent wilting point" (PWP). The total amount of water available for plant uptake is the "available water" (AW), which is the difference between FC and PWP (Fig. 8) and is often expressed as a percent by volume (volume of water/volume of sample). The "plant-available water" (PAW) is determined by multiplying the AW (in units of water depth) by the root zone depth where water extraction occurs. Depletion of the water content to PWP adversely impacts plant health and yield. Thus, for irrigation purposes, a "maximum allowable depletion" (MAD) or fraction of PAW representing the plant "readily available water" (RAW) is essentially the operating range of soil water content for irrigation management. Theoretically, irrigation scheduling consists of irrigating at a low threshold corresponding to a water content at a given MAD and irrigating until the depleted water has been replaced to but not more than the FC level; otherwise, drainage and/or deep percolation will occur.

\section{Irrigation control strategies for vegetable crops}

Irrigation control strategy goals of providing optimum soil moisture for plant growth, productivity, and reduction of fertilizer nutrient leaching. The following section describes irrigation control options and the technologies involved in each.

SOIL MOISTURE SENSOR-BASED IRRIGATION CONTROL. There are two fundamental types of irrigation control when sensors are used, ondemand and bypass (Dukes and Muñoz-Carpena, 2005). On-demand irrigation control consists of a control system that irrigates in response to soil moisture measurements in the irrigated zone to maintain soil moisture content within low and high thresholds (i.e., to maintain soil water content within RAW). Thus, this type of control system must determine when to start and when to end irrigation. This type of control system has been used on sweet corn research in

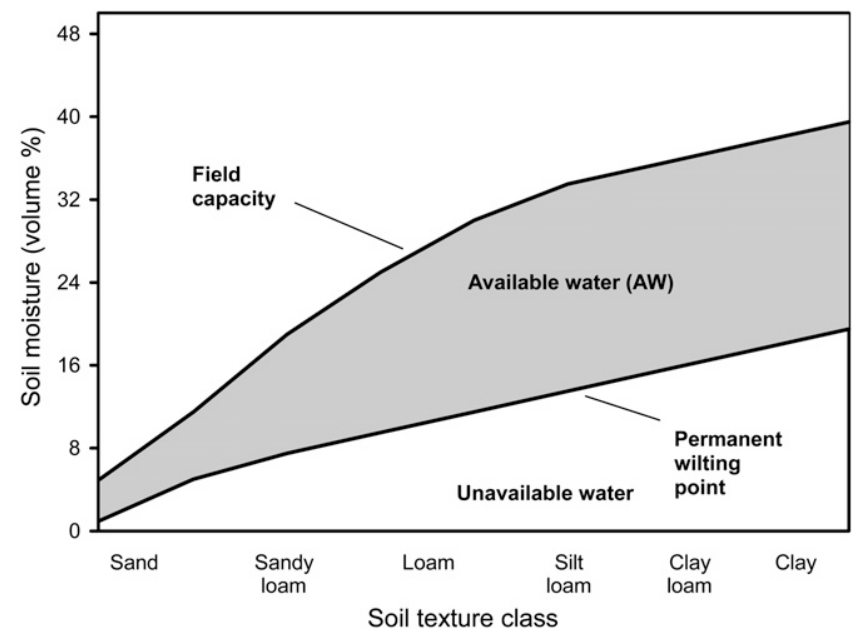

Fig. 8. General relationship between readily available water, field capacity, permanent wilting point, and soil unavailable water and soil texture class.

Florida (Dukes and Scholberg, 2005), on green bell pepper (Dukes et al., 2007a), and is currently being used with promising results for golf course fairway irrigation control (M.D. Dukes, unpublished data). On-demand control is controllerand sensor-intensive. That is to say that there is little room for error in the control system or sensor performance. Alternatively, bypass control simply bypasses timed irrigation events when measured soil moisture exceeds preset thresholds (e.g., field capacity as the upper limit). This type of control is simpler from a controller standpoint; however, the user must program the number and length of irrigation events to correspond to plant water requirements. Bypass control has a long history in Florida irrigation research starting in the 1980 s on vegetables and turfgrass research with switching tensiometers. Bypass control is currently being researched in Florida on tomato, zucchini (Cucurbita pepo), green bell pepper (Zotarelli et al., 2008a, 2009), turfgrass, and landscapes (Dukes et al., 2007b) with capacitance-based soil moisture sensor irrigation controllers.

As an irrigation scheduling method, sensors have been promoted for many years and have been used to some extent in various types of agriculture. Muñoz-Carpena et al. (2005a) provided a comprehensive review of types of sensors used to measure soil moisture content. Generally, there are two types of sensors that are used for irrigation scheduling, those that measure soil water potential (also called tension or suction) and those that measure volumetric water content directly.

Dukes and Muñoz-Carpena (2005) summarized some advantages and disadvantages of both types of sensors. Within the category of volumetric sensors, capacitance-based sensors have become common in recent years as a result of a decrease in the cost of electronic components and increased reliability of these types of sensors. However, a variety of sensors are available on the market that have substantially different accuracies, response to salts, and cost.

VEgETABLE PRODUCTION USING SENSOR BASED IRRIGATION CONTROL. Increase in crop production with reduced soil moisture tension using 
tensiometers has been documented (Clark et al., 1991). Simple soil water status sensors (e.g., tensiometers) have been used for many years as devices used to give growers feedback on when to irrigate. Tensiometers are viable devices for this purpose; however, they require constant maintenance to keep them refilled and to maintain water within the water column free of dissolved air.

Many researchers have examined the use of sensor-based control systems in vegetable production (Table 1). As a result of documented maintenance issues (e.g., Smajstrla and Koo, 1986), tensiometer-based automatic control is not practiced in Florida vegetable or citrus production and use of tensiometers for manual irrigation is limited. The first attempts at irrigation automation used switching tensiometers that have a magnetic switch that opens the irrigation control circuit bypassing timed events when the measured tension exceeds the switch set point. Smajstrla and Locascio (1996) used switching tensiometers to control drip irrigation of fresh market tomato. These switching tensiometers automatically initiated up to three daily irrigation events. Irrigation durations were determined by half pan evaporation of the previous week and events varied from 30 to $90 \mathrm{~min}$ as environmental demands increased throughout the season. The highest yields in a 4-year study were achieved with a 1.45 psi tensiometer set point, which is equivalent to $10 \%$ volumetric water content for the Arredondo fine sand (hyperthermic Grossarenic Paleudults) at the study site. Irrigation applied at this threshold was reported as ranging from $\approx 6.3$ to 8.85 inches depending on study year. Problems associated with tensiometers for use in automated irrigation systems have been reported as needing frequent maintenance as well as clogging as a result of algae growth (Smajstrla and Koo, 1986).

Granular matrix resistance sensors have been manufactured for a number of years as a replacement for tensiometers. However, these sensors have been shown to require special calibration for coarse Florida soils (Irmak and Haman, 2001). When used for vegetable irrigation control on gravelly loam soil in southern Florida, granular matrix sensors performed erratically and did not reduce water application compared with a time-based schedule (MuñozCarpena et al., 2005b). Similarly,
Cardenas-Lailhacar et al. (2008) found that granular matrix sensorbased irrigation controllers were no more effective than a rain sensor for turfgrass irrigation control on a fine sand soil. These sensors have been used successfully to irrigate onion and potato on moderately heavy soil (Shock et al., 2002).

Capacitance [e.g., time domain reflectometry (TDR) and frequency domain reflectometry]-based soil moisture measurement devices have been shown to have relatively accurate soil moisture measurement in sandy soils common to Florida (Irmak and Irmak, 2005). Dukes and Scholberg (2005) installed an automatic irrigation control system based on research grade TDR soil moisture probes and microcontrollers for irrigation of sweet corn. Irrigation was initiated based on preset low soil moisture thresholds and ended based on an upper threshold. This control system was coupled with a subsurface drip irrigation system with a drip tube buried under each row at 23 and $33 \mathrm{~cm}$ in two different treatments. The 23-cm deep treatment under automatic control reduced irrigation $11 \%$ relative to sprinkler irrigation typically used by growers. Dukes et al. (2003) used

Table 1. Literature summary of automatic irrigation control systems used in Florida vegetable research.

\begin{tabular}{|c|c|c|c|}
\hline Author & Crop & $\begin{array}{l}\text { Automatic irrigation } \\
\text { control system (AICS) }\end{array}$ & Research findings \\
\hline $\begin{array}{l}\text { Smajstrla and } \\
\text { Locascio, } 1996\end{array}$ & Tomato & Switching tensiometers & $\begin{array}{l}\text { Reduced irrigation requirements of tomato by } 40 \% \\
\text { to } 50 \% \text { without reducing yields compared with } \\
\text { fixed schedule (three to five times per week) }\end{array}$ \\
\hline Dukes et al., 2003 & Pepper & $\begin{array}{l}\text { Capacitance-based soil moisture } \\
\text { probe, time domain } \\
\text { transmission (TDT) }\end{array}$ & $\begin{array}{l}\text { Use of } 50 \% \text { less irrigation water, similar yields } \\
\text { compared with a daily based on Class A pan } \\
\text { evaporation irrigation method }\end{array}$ \\
\hline $\begin{array}{l}\text { Dukes and } \\
\text { Scholberg, } 2005\end{array}$ & Sweet corn & TDR soil moisture probes & $\begin{array}{l}\text { Up to } 11 \% \text { of reduction in water use using AICS } \\
\text { with subsurface drip irrigation compared with } \\
\text { sprinkler irrigation without affecting yields }\end{array}$ \\
\hline $\begin{array}{l}\text { Muñoz-Carpena } \\
\text { et al., } 2006\end{array}$ & Tomato & $\begin{array}{l}\text { Switching tensiometers and } \\
\text { granular matrix sensor } \\
\text { based irrigation controllers }\end{array}$ & $\begin{array}{l}\text { Switching tensiometers at the } 15 \mathrm{kPa}(0.15 \mathrm{bar}) \\
\text { set point resulted to up to } 73 \% \text { reduction in } \\
\text { water use when compared with the control }\end{array}$ \\
\hline $\begin{array}{l}\text { Zotarelli et al., } \\
\text { 2008a }\end{array}$ & Zucchini & $\begin{array}{l}\text { Capacitance-based soil moisture } \\
\text { probe, TDT }\end{array}$ & $\begin{array}{l}\text { Reduction in water use by } 30 \% \text { to } 80 \% \text { compared } \\
\text { with the single, daily fixed-time irrigation, } \\
\text { significant reduction in nitrogen leaching, } \\
\text { increase in yield and nitrogen use efficiency }\end{array}$ \\
\hline $\begin{array}{l}\text { Zotarelli et al., } \\
2009\end{array}$ & Tomato & $\begin{array}{l}\text { Capacitance-based soil moisture } \\
\text { probe, TDT }\end{array}$ & $\begin{array}{l}\text { Irrigation water savings superior to } 67 \% \text { compared } \\
\text { with the control, yield increment of } 11 \% \text { to } 26 \%\end{array}$ \\
\hline
\end{tabular}


a simple soil moisture-based control system to automatically maintain a relatively constant soil moisture content in the root zone of green bell pepper through high-frequency irrigation based on soil moisture measurements by the control system. Compared with manual irrigation treatments with one or two irrigation events per day with similar yield, irrigation amount was reduced by $\approx 50 \%$. Capacitance-based soil moisture sensors do not require maintenance once installed in contrast to tensiometers that require weekly (Muñoz-Carpena et al., 2005a) or biweekly maintenance (Smajstrla and Locascio, 1996) to maintain accuracy. Soil moisture sensor irrigation control has been used on drip-irrigated zucchini to increase yield by $35 \%$, irrigation water use efficiency by $274 \%$, and nitrogen use efficiency by $40 \%$ relative to single, daily timed irrigation representative of grower practices (Zotarelli et al., 2008a). In general, this study found that a simple and inexpensive irrigation controller coupled with commercially available soil moisture probes (MuñozCarpena et al., 2008) was effective at reducing both irrigation water application and nitrogen leaching under several drip irrigation configurations. Zotarelli et al. (2009) reported irrigation savings of $40 \%$ to $65 \%$ less than typical grower-based time irrigation scheduling while increasing tomato yield $11 \%$ to $45 \%$. Similar results reducing irrigation application and drainage while maintaining green bell pepper yields on sandy soils have been reported for Florida conditions (Dukes et al., 2006).

A number of researchers have shown that excessive irrigation on vegetables may cause yield decreases relative to optimum irrigation amounts as determined by soil moisture sensor control on green bell pepper (Dukes et al., 2003) as determined by pan evaporation for a yield decrease in high irrigation rates on fresh market tomato in one of two seasons (Locascio et al., 1989) and as shown on fresh market tomato in southern Florida (Muñoz-Carpena et al., 2005b).

\section{Nitrogen leaching: fertigation versus irrigation}

Fertigation is the application of nutrients through the irrigation system. Fertigation is a widespread practice for microirrigated vegetable and fruit crops in Florida, providing growers with the opportunity to apply nutrients more frequently in quantities that closely match short-term crop nutrient requirements (Hartz and Hochmuth, 1996; Hochmuth, 1992).

This results in higher fertilizer use efficiency by the crop as well as a reduction of nutrient leaching below the plant root zone. However, in soils with poor water retention such as sandy soils, application of excess water may promote displacement of nutrients before complete uptake has occurred (Dukes and Scholberg, 2005; Zotarelli et al., 2008b, 2009). Appropriate irrigation scheduling and matching irrigation amounts with the water-holding capacity of the effective root zone thus may provide ways to minimize the incidence of excess nitrogen leaching associated with overirrigation. Figure 9 shows the effectiveness of appropriate irrigation scheduling to reduce the volume of water percolated in the soil profile compared with fixed-time irrigation.

As described in the previous section, uniformity of water application also drives the uniformity of the fertilizer application. Therefore, high water application uniformity is essential for proper fertigation. The drip system needs to be completely pressurized before the fertigation begins to avoid uneven application rates. In addition, the fertilizer used must be completely soluble in water and pass through the filters to ensure that any undissolved fertilizer particles are filtered out of the drip system. Injecting nitrogen fertigation toward the end of the irrigation cycle may also prevent immediate nitrogen displacement below the soil region with highest root concentration (Scholberg, 1996). Alternatively, monitoring of soil electrical conductivity (EC) sensors has the potential for estimating variation in nutrient displacement in the crop root zone to improve fertigation and

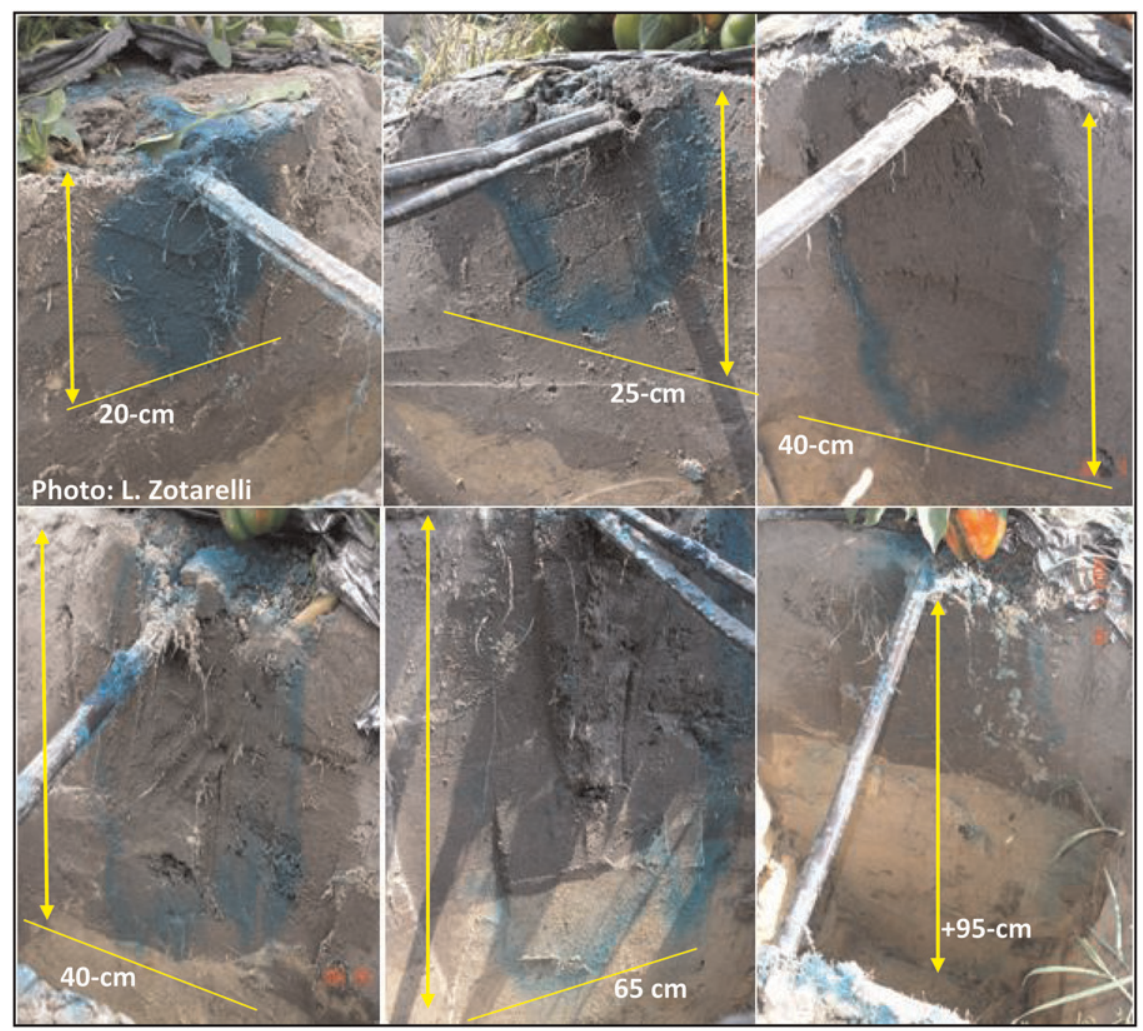

Fig. 9. Demonstration of the effectiveness of soil moisture sensor-based irrigation systems in enhancing nutrient retention for soil moisture sensor irrigation (top row) resulting from small, frequent irrigation events compared with fixed-time irrigation schedule with single daily large irrigation events (bottom row) applying dye through the fertigation drip lines. Soil moisture sensor irrigation (top row) and fixed-time schedule irrigation (bottom row) at after $24 \mathrm{~h}$ (left), after $3 \mathrm{~d}$ (center), and after $7 \mathrm{~d}$ (right) of the injection of dye; $1 \mathrm{~cm}=0.3937 \mathrm{inch}$. 
irrigation management. However, little information is available on the effectiveness of EC sensors on irrigation/fertigation management for vegetable crops in Florida.

\section{Potential use of irrigation technologies and future research priorities}

As outlined in this review, soil moisture sensor-based irrigation of vegetable crops has shown strong potential for saving irrigation water. Advances in soil moisture sensors and irrigation controllers have made them easier to use and the cost of energy has made the sensor a more viable alternative. In the past, soil moisture sensors have not been used widely by growers as a result of costs, the level of technical skill required, and sensor maintenance required. Continued restrictions aimed at reducing nutrient leaching and recent increases in energy costs have increased grower interest in use of improved technologies reviewed in this article. However, more work is needed to develop irrigation scheduling recommendations and automated control systems that the majority of vegetable crop growers would use. Detailed analysis of sensor position in microirrigated crops, particularly plastic-mulched vegetable systems, is needed. The use of EC probes to track fertilizer movement would aid growers in development of more effective irrigation and/or fertigation management with the potential of reduced nutrient leaching. Guidelines on commercial automatic soil moisture-based irrigation controls as a BMP should be developed for vegetables. The grower guidelines should include number of sensors required and optimum placement relative to varying soil conditions of commercial production. An economic assessment of costs associated with and benefits derived from conversion of irrigation systems in vegetables from seepage to drip irrigation needs to be made to promote water conservation by vegetable growers in southern Florida. Current work on the assessment of fertilizer application method and nutrient distribution uniformity in vegetables and at various rates is needed.

\section{Literature cited}

Boman, B.J. 2002. Efficiency, uniformity, and system evaluation, p. 399-414. In:
B.J. Boman (ed.). Water and Florida citrus: Use, regulation, systems, and management. Inst. Food Agr. Sci., Univ. Florida Press, Gainesville, FL.

Cardenas-Lailhacar, B., M.D. Dukes, and G.L. Miller. 2008. Sensor-based automation of irrigation on bermudagrass, during wet weather conditions. J. Irrig. Drain. Eng. 134:120-128.

Clark, G.A., C.D. Stanley, D.N. Maynard, G.J. Hochmoth, E.A. Hanlon, and D.Z. Haman. 1991. Water and fertilizer management of microirrigated fresh market tomatoes. Trans. Amer. Soc. Agr. Eng. 321:429-435.

Dukes, M.D. 2006. Effect of wind speed and pressure on linear move irrigation system uniformity. Appl. Eng. Agr. 22:541-548.

Dukes, M.D. and R. Muñoz-Carpena. 2005. Soil water sensor based automatic irrigation of vegetable crops. Encyclopedia of water science. Marcel Dekker, New York, NY.

Dukes, M.D., R. Muñoz-Carpena, L. Zotarelli, J. Icerman, and J.M. Scholberg. 2007a. Soil moisture-based irrigation control to conserve water and nutrients under drip irrigated vegetable production. Jornada de Investigación en la Zona no Saturada 8:229-236.

Dukes, M.D., B. Cardenas-Lailhacar, S. Davis, M.B. Haley, and M. Shedd. 2007b. Smart water application technology (SWAT) evaluation in Florida. Amer Soc. Agr. Biol. Eng. Paper No. 07-2250.

Dukes, M.D. and C.D. Perry. 2006. Uniformity testing of variable rate center pivot irrigation control systems. Precis. Agr. 7:205-218.

Dukes, M.D. and J.M. Scholberg. 2005. Soil moisture controlled subsurface drip irrigation on sandy soils. Appl. Eng. Agr. 21:89-101.

Dukes, M.D., E.H. Simonne, W.E. Davis, D.W. Studstill, and R. Hochmuth. 2003. Effect of sensor-based high frequency irrigation on bell pepper yield and water use. Proc. Intl. Conf. Irr. Drainage $2: 665-674$

Dukes, M.D., L. Zotarelli, J.M. Scholberg, and R. Muñoz-Carpena. 2006. Irrigation and nitrogen best management practices under drip-irrigated vegetable production. Proc. World Water Environ. Res. Congr. 2006:1-11.

Florida Department of Agriculture and Consumer Services. 2007. Florida agriculture statistical directory 2007. 22 Oct. 2008. <http://www.florida-agriculture. com/pubs/pubform/pdf/Florida Agricultural_Statistical_Directory.pdf>.
Frost, K.R. and H.C. Schwalen. 1960. Evapotranspiration during sprinkler irrigation. Trans. Amer. Soc. Agr. Eng. 3:18-20.

Haman, D.Z., A.G. Smajstrla, and D.J. Pitts. 2005. Efficiencies of irrigation systems used in Florida nurseries. Inst. Food Agr. Sci., Univ. Florida, Bul. 312.

Hartz, T.K. and G.J. Hochmuth. 1996. Fertility management of drip-irrigated vegetables. HortTechnology 6:168-172.

Hochmuth, G.J. 1992. Fertilizer management for drip-irrigated vegetables in Florida. HortTechnology 2:27-32.

Hochmuth, R.C. 2007. Vegetable growers get irrigation help. Citrus Vegetables 71:28.

Howell, T.A. 2001. Enhancing water use efficiency in irrigated agriculture. Agron. J. 93:281-289.

Irmak, S. and D.Z. Haman. 2001. Performance of the Watermark ${ }^{\circledR}$ granular matrix sensor in sandy soils. Appl. Eng. Agr. 17:787-795

Irmak, S. and A. Irmak. 2005. Performance of frequency domain reflectometry, capacitance, and psuedo-transit timebased soil water content probes in four coarse-textured soils. Appl. Eng. Agr. 21:999-1008.

Kohl, K.D., R.A. Kohl, and D.W. DeBoer. 1987. Measurement of low pressure sprinkler evaporation loss. Trans. Amer. Soc. Agr. Eng. 30:1071-1074.

Locascio, S.J. 2005. Management of irrigation for vegetables: Past, present, and future. Hort Technology 15:482-485.

Locascio, S.J., S.M. Olson, and F.M. Rhoads. 1989. Water quantity and time of $\mathrm{N}$ and $\mathrm{K}$ application for trickle-irrigated tomatoes. J. Amer. Soc. Hort. Sci. 114:265-268.

Marella, R.L. 1999. Water withdrawals, use, discharge, and trends in Florida, 1995. U.S. Geological Survey, Reston, VA. Water-Resources Investigations Rpt. 99-4002.

Muñoz-Carpena, R., A. Ritter, and D.D. Bosch. 2005a. Field methods for monitoring soil water status, p. 167-195. In: J. Alvarez-Benedi and R. Muñoz-Carpena (eds.). Soil-water-solute process characterization. CRC Press, Boca Raton, FL.

Muñoz-Carpena, R., Y. Li, and T. Olczyk. 2005 b. Alternatives of low cost soil moisture monitoring devices for vegetable production in south Miami Dade County, Florida Coop. Ext. Serv., Inst. Food Agr. Sci., Univ. Florida, ABE 333. 22 Oct. 2008. <http://edis.ifas.ufl.edu/ AE230>. 
Muñoz-Carpena, R., M.D. Dukes, Y. Li, and W. Klassen. 2006. Field comparison of tensiometer and granular matrix sensor automatic drip irrigation on tomato. HortTechnology 15:584-590.

Muñoz-Carpena, R., M.D. Dukes, Y. Li, and W. Klassen. 2008. Design and field evaluation of a new controller for soilwater based irrigation. Appl. Eng. Agr. 24:183-191.

Nogueira, L.C., M.D. Dukes, D.Z. Haman, J.M. Scholberg, and C. Cornejo. 2003. Data acquisition system and irrigation controller based on CRI0X datalogger and TDR sensor. Soil Crop Sci. Soc. Florida Proc. 62:38-46.

Obreza, T.A. 2004. Maintenance guide for Florida microirrigation systems. Florida Coop. Ext. Serv., Inst. Food Agr. Sci., Univ. Florida, Circ. 1449. 22 Oct. 2008. <http://edis.ifas.ufl.edu/SS436>.

Pandey, C., S. Shukla, and T.A. Obreza. 2007. Development and evaluation of soil moisture-based seepage irrigation management for water use and quality. J. Irrig. Drain. Eng. 133:435-443.

Scholberg, J.M.S. 1996. Adaptive use of crop growth models to simulate the growth of field-grown tomato. $\mathrm{PhD}$ Diss. Univ. Florida, Gainesville, FL.

Shock, C.C., E.B.G. Feibert, L.D. Saunders, and E.P. Eldredge. 2002. Automation of subsurface drip irrigation for crop research. Proc. World Congr. Computers Agr. Natural Resources 1:809-816.

Simmone, E.H., M.D. Dukes, and D.Z. Haman. 2007. Principles and practices of irrigation management for vegetables. Inst. Food Agr. Sci., Univ. Florida, AE 260.

Smajstrla, A.G., B.J. Boman, G.A. Clark, D.Z. Haman, D.S. Harrison, F.T. Izuno, D.J. Pitts, and F.S. Zazueta. 2002. Efficiencies of Florida agricultural irrigation systems. Inst. Food Agr. Sci., Univ. Florida, Bul. 247.

Smajstrla, A.G., B.J. Boman, D.Z. Haman, F.T. Izuno, D.J. Pitts, and F.S. Zazueta. 2004. Basic irrigation scheduling in Florida. Inst. Food Agr. Sci., Univ. Florida, Bul. 249

Smajstrla, A.G. and D.Z. Haman. 1998. Irrigated acreage in Florida: A summary through 1998. Inst. Food Agr. Sci., Univ. Florida, Bul. CRI220. 22 Oct. 2008. $<$ http://edis.ifas.ufl.edu/AE150>.

Smajstrla, A.G. and R.C. Koo. 1986. Use of tensiometers for scheduling of citrus trickle irrigation. Proc. Florida State Hort. Soc. 99:51-56.

Smajstrla, A.G. and S.J. Locascio. 1996. Tensiometer-controlled, drip-irrigation scheduling of tomato. Appl. Eng. Agr. 12:315-319.

Solley, W.B., R.R. Pierce, and H.A. Perlman. 1998. Estimated use of water in the United States in 1995. U.S. Geol. Surv. Circ. 1200.71 p.

U.S. Department of Agriculture. 1998. Estimating soil moisture by feel and appearance. Natural Resources Conservation Serv., Program Aid No. 1619. 22 Oct. 2008. <ftp://ftp-fc.sc.egov.usda. gov/MT/www/technical/>.
U.S. Department of Agriculture. 2004a. 2002-Census of agriculture, farm and ranch irrigation Survey 2003. 22 Oct. 2008. <http://www.nass.usda.gov/ census/census $02 />$.

U.S. Department of Agriculture. 2004b. 2002 Census of agriculture, Vol. 1, Ch. 1, Florida state level data. 22 Oct. 2008. <http://www.nass.usda.gov/census / census02/volumel/fl/indexl.htm >.

U.S. Department of Agriculture. 2008a. Vegetable and melons: U.S. farm cash receipts, 1996-2007. 22 Oct. 2008. <http://www.ers.usda.gov/Publications/ vgs/Tables/Receipt.pdf $>$.

U.S. Department of Agriculture. 2008b. Vegetables, Apr. 2008 Rpt. 22 Oct. 2008. $<$ http://usda.mannlib.cornell.edu/usda/ current/Vege/Vege-04-03-2008.pdfs.

Zotarelli, L., M.D. Dukes, J.M. Scholberg, T. Hanselman, K.L. Femminella, and R. Muñoz-Carpena. 2008a. Nitrogen and water use efficiency of zucchini squash for a plastic mulch bed system on a sandy soil. Scientia Hort. 116:8-16.

Zotarelli, L., J.M. Scholberg, M.D. Dukes, and R. Muñoz-Carpena. 2008b. Fertilizer residence time affects nitrogen uptake efficiency and growth of sweet corn. J. Environ. Qual. 37:1271-1278.

Zotarelli, L., J.M. Scholberg, M.D. Dukes, R. Muñoz-Carpena, and J. Icerman. 2009. Tomato yield, biomass accumulation, root distribution and water use efficiency on a sandy soil, as affected by nitrogen rate and irrigation scheduling. Agr. Water Mgt. 96:23-34. 